\title{
Pathogenesis of Antineutrophil Cytoplasmic Autoantibody-Associated Vasculitis and Potential Targets for Biologic Treatment
}

\author{
J.S.F. Sanders $^{a}$ W.H. Abdulahad ${ }^{b}$ C.A. Stegeman ${ }^{a}$ C.G.M. Kallenberg ${ }^{b}$ \\ ${ }^{a}$ Department of Internal Medicine, Division of Nephrology, and b Department of Clinical Immunology and Rheumatology, \\ University Medical Center Groningen, University of Groningen, Groningen, The Netherlands
}

\section{Key Words}

Antineutrophil cytoplasmic autoantibody-associated vasculitis - Granulomatosis with polyangiitis - Microscopic polyangiitis · Glomerular disease $\cdot$ Biological therapy

\begin{abstract}
Antineutrophil cytoplasmic autoantibody (ANCA)-associated vasculitides (AAV) are autoimmune diseases in which the small vessels are inflamed. Clinical observations suggest a pathogenic role for ANCA. Such a role is supported by in vitro experimental data and animal models, particularly for myeloperoxidase-ANCA. An in vivo pathogenic role of ANCA directed to proteinase 3 has, however, not been fully substantiated. Additionally, the pathogenic role of B cells, T cells, and the alternative pathway of complement in AAV have been elucidated. Insight into these pathogenic pathways involved in AAV has opened and will further open new ways for targeted biologic treatment. In this review the pathogenesis of AAV and potential targets for biologic treatment are discussed.
\end{abstract}

(c) 2014 S. Karger AG, Basel

\section{Introduction}

Since the ChapelHill Consensus Conference (CHCC), vasculitides have been defined according to the size of the involved vessels, the histopathology of the lesions, and clinical findings. Granulomatosis with polyangiitis (GPA, formerly known as Wegener's granulomatosis), microscopic polyangiitis (MPA), and eosinophilic GPA (EGPA, formerly known as Churg-Strauss syndrome) are primary vasculitides primarily affecting small vessels, i.e. small arteries, arterioles, capillaries, and venules [1]. GPA is hallmarked by the classic triad of small-vessel vasculitis, extravascular necrotizing granulomatous inflammation, and pauci-immune necrotizing crescentic glomerulonephritis. MPA is defined as necrotizing vasculitis, with few or no immune deposits, that predominantly affects small vessels, but without the typical granulomatous inflammation present in GPA. Finally, EGPA is characterized by asthma, eosinophilia, and small-vessel vasculitis. Collectively, they are designated as antineutrophil cytoplasmic autoantibody (ANCA)associated vasculitides (AAV). As EGPA is clinically different from the other AAV, it is beyond the scope of this review.

The AAV are characterized by the presence of autoantibodies against either proteinase 3 (PR3) or myeloperoxidase (MPO), which are enzymes contained in the primary granules of neutrophils and peroxidase-

Biologic Treatment in Glomerular Disease

D. Jayne, Cambridge

V. Tesar, Prague

\section{KARGER}

E-Mail karger@karger.com

www.karger.com/nec
(C) 2014 S. Karger AG, Basel

$1660-2110 / 14 / 1284-0216 \$ 39.50 / 0$
J.S.F. Sanders, MD, $\mathrm{PhD}$

Department of Internal Medicine, Division of Nephrology

University Medical Center Groningen

Hanzeplein 1, NL-9713 GZ Groningen (The Netherlands)

E-Mail j.sanders@ umcg.nl 
positive lysosomes of monocytes [1]. A recent genomewide association study has shown that PR3-ANCA versus MPO-ANCA-positive AAV patients display distinct genetic associations - even more than their associated diseases, GPA and MPA, respectively [2]. PR3- and MPO-AAV are also characterized by clinical and histopathological differences irrespective of the associated diseases, i.e. GPA and MPA. Renal-limited disease occurs mainly in MPO-AAV. In contrast, PR3AAV patients show more widespread extrarenal organ involvement [3]. Additionally, PR3-ANCA is strongly associated with upper and lower respiratory tract granulomatous inflammation. Finally, patients with PR3$\mathrm{AAV}$ are at increased risk to experience relapses of disease [4-6].

\section{Pathogenesis of AAV and Conventional Therapy}

A central event in the effector phase of the disease is ANCA-mediated neutrophil activation, which leads to degranulation of proteolytic enzymes, oxygen radical production, and amplification of the inflammatory response via activation of the alternative pathway of the complement system [7]. Eventually, these effects result in vasculitis and lead to organ dysfunction with renal failure as a prominent manifestation. Conventional therapy of AAV was introduced in the 1970s and consists of administration of cyclophosphamide together with steroids, which induces remission in the majority of patients $[8,9]$. Subsequently, cumulative cyclophosphamide dosages have been reduced by switching therapy after induction of remission to maintenance with azathioprine or methotrexate $[10,11]$. However, conventional therapy is associated with severe side effects and often fails to restore renal function. In patients who needed renal replacement therapy at diagnosis at our center, $29 \%$ did not regain renal function and 23\% died within 6 months [12]. Also, in this cohort approximately $50 \%$ of patients with PR3-AAV experienced a relapse within 5 years after diagnosis accompanied by increasing renal damage [12]. In individual patients it is difficult to predict if and when a relapse will occur. Thus, the main challenges in the field of AAV are to develop more specific and less toxic therapies, and to identify markers that will improve monitoring of disease activity and predict impending relapses. To meet these challenges, a better understanding of the key pathogenic pathways involved in AAV is essential. This might subsequently result in new targets for therapy.

AAV: Pathogenesis and Targets for

Treatment

\section{Arguments for a Pathogenic Role of ANCA}

In the great majority of patients with AAV, ANCA can be detected. After successful induction of remission, ANCA titers decrease or disappear in many patients. However, the relation between ANCA levels and disease activity is not straightforward, limiting its clinical use. In a previous retrospective study we found that patients with PR3-AAV who remain ANCA positive after induction of remission have increased risk of experiencing a relapse [13]. Also, after successful induction of remission, rises in ANCA may precede a relapse. However, this relation is far from perfect and the time to event relation may be over 6 months [14]. Tomasson et al. [15] recently performed a meta-analysis of nine studies and found that a rise in or persistence of ANCA during remission was only modestly predictive for disease relapse. Finally, a strong argument for a pathogenic role of MPO-ANCA comes from the observation of glomerulonephritis and pulmonary hemorrhage in a neonate born from a mother with MPO-AAV. Transient occurrence of vasculitis in the neonate was thought to be caused by transplacental transfer of MPO-ANCA [16]. Thus, data from clinical observations suggest, but do not prove, that ANCAs are pathogenic.

A pathogenic role for MPO-ANCA is suggested by in vivo animal studies. Xiao et al. [17] immunized MPOdeficient mice with mouse MPO. As a result, these mice developed an immune response to mouse MPO. Next, splenocytes from these mice were transferred to immunodeficient and normal mice. These recipient mice developed pauci-immune necrotizing crescentic glomerulonephritis and systemic necrotizing small-vessel vasculitis. Transfer of IgG alone from these MPO-deficient mice immunized with MPO into normal mice resulted in pauci-immune focal necrotizing crescentic glomerulonephritis. Little et al. [18] induced anti-MPO necrotizing vasculitis in Wistar-Kyoto rats by immunizing rats with human MPO. The development of a model for PR3ANCA disease has not been as successful, although promising models are being developed. Splenocyte transfer from autoimmunity-prone nonobese diabetic (NOD) mice immunized with murine PR3 to nonobese diabetic-severe combined immunodeficiency mice resulted in the development of vasculitis and severe glomerulonephritis, but not in granuloma formation [19]. Recently, a model was described in which mice received human hematopoietic stem cells, which resulted in a human-mouse chimeric immune system. After passive transfer of PR3-ANCA, the mice developed mild glo-

Nephron Clin Pract 2014;128:216-223

217 


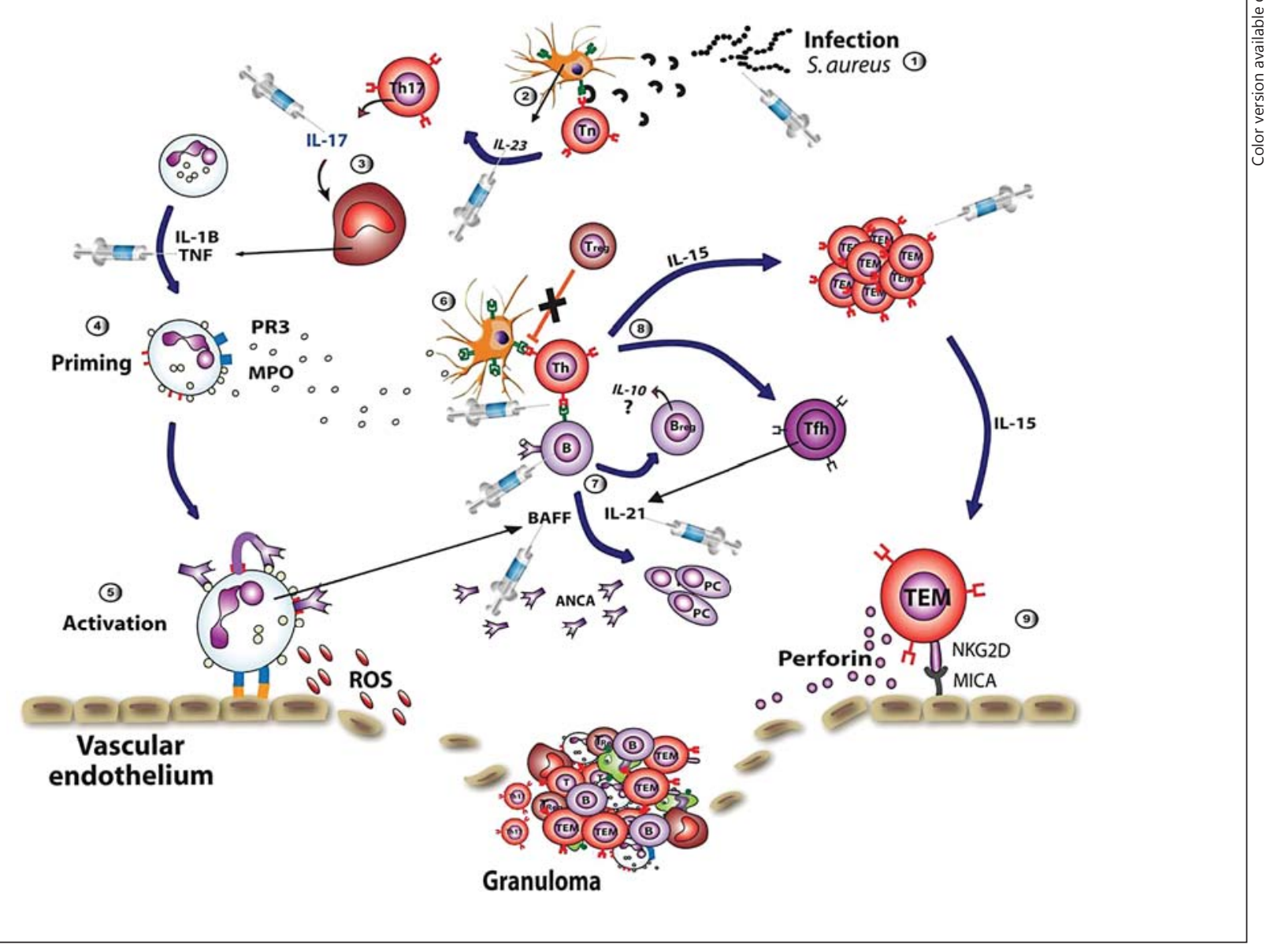

Fig. 1. A proposed model of disease mechanisms and therapeutic applications for autoimmune modulation in ANCA-associated systemic vasculitis. (1) Superantigens and peptidoglycans from Staphylococcus aureus stimulate antigen-presenting cells in the respiratory tract to produce IL-23 (2), which then induces skewing in the T cell response towards Th17 cells and release of IL-17 (3). IL-17 promotes the release of the proinflammatory cytokines IL$1 \beta$ and TNF- $\alpha$ from macrophages, which are essential for the priming of neutrophils (membrane expression of PR3) and upregulation of adhesion molecules on their surface as well as on the vascular endothelium (4). IL-17 also induces chemokine secretion in bronchial epithelial cells that attract primed neutrophils to the infected tissue, which subsequently adhere to the endothelial cells (5). Released PR3 from neutrophils can be processed and presented by antigen-presenting cells/B cells to $\mathrm{T}$ cells (6). As $\mathrm{T}$ regulatory cells $\left(\mathrm{T}_{\text {reg }}\right)$ fail to inhibit this autoimmune response in GPA, an autoreactive immune response can proceed, in which $B$ cells can differentiate to ANCA-producing plasma cells (7), whereas T cells might undergo repeated stimulation by PR3-pulsed antigen-presenting cells resulting in a pool of $\mathrm{T}_{\mathrm{EM}}$ cells including IL-17-pro- ducing Th cells and T-follicular helper (Tfh) cells that produce IL-21 (8). ANCA can also induce the release of BAFF from activated neutrophils. Both BAFF and IL-21 (released from Tfh cells) synergize in stimulating plasma cell differentiation and promote the survival of autoreactive B cells (7). Deficiency or dysfunction of regulatory $B$ cells results in failure to inhibit both autoreactive $B$ and T cells. ANCAs activate neutrophils that adhere to endothelial cells, resulting in local production of reactive oxygen species (ROS) and release of proteolytic enzymes that damage vascular endothelial cells (5). Moreover, the expanded population of CD4+ $\mathrm{T}_{\mathrm{EM}}$ cells in peripheral blood, resulting from persistent activation by PR3, upregulate their NKG2D cytotoxic protein and remain in the circulation during remission. When the disease becomes active, the MICA protein is upregulated on several vascular endothelial cells (especially in the kidney), which attract $\mathrm{T}_{\mathrm{EM}}$ cells to the inflammatory areas (9). The MICA protein on the target cells can bind to NKG2D on the $\mathrm{T}_{\mathrm{EM}}$ cells, which in turn enhances their cytotoxic function to kill the target cell in a perforin- and granzymedependent way, ending in vasculitis (from Lepse et al. [57] with permission). 
merulonephritis and lung hemorrhage, but no granuloma formation was detected [20].

In conclusion, data from animal studies clearly suggest, if not prove, a pathogenic role for MPO-ANCA. Subsequent studies in the MPO-ANCA animal models have elucidated the various pathways involved, enabling testing of targeted treatment. A limitation is the absence of an animal model for granulomatous inflammation in PR3-AAV.

\section{Anti-TNF-a Therapy}

Owing to the importance of TNF- $\alpha$ in the mechanisms of inflammation, TNF- $\alpha$ blockers have been widely used for the treatment of autoimmune diseases. Also in GPA, after small studies in refractory disease showed promising results, a randomized trial was initiated [21]. However, the randomized placebo-controlled trial evaluating the efficacy of etanercept, one of the TNF- $\alpha$ inhibitors, in addition to standard of care, failed to show higher efficacy in the achievement of sustained remission in GPA patients compared to placebo [22]. Additionally, in this study more solid malignancies were initially observed in the intervention group, although during long-term follow-up this could not be solely attributed to etanercept use [23]. A steroid-sparing role of the TNF- $\alpha$ inhibitors infliximab and adalimumab in remission induction has been suggested in small uncontrolled studies [21]. Currently, however, TNF- $\alpha$ inhibitors are not recommended in AAV.

\section{B cells}

The major breakthrough of the last decade in AAV has been the introduction of B cell-targeted therapy $[5,24]$. The RAVE trial showed equivalence of rituximab B celltargeted therapy to standard immunosuppressive therapy $[5,6]$. These clinical studies have led to great interest in the role of B cells in AAV, but their exact role is not completely clear. B cells are present in lesions in patients with $\mathrm{AAV}$ and they are the precursors of ANCA-producing plasma cells; however, B cells are also critical players in the regulation of immune responses [25]. With the success of B cell-targeted therapy by rituximab, other B celldepleting agents could have clear therapeutic potential in $\mathrm{AAV}$. Ofatumumab is a novel, potentially more potent anti-CD20 monoclonal antibody [26]. It binds CD20 with greater avidity leading to greater complement-dependent cytotoxicity. Other B cell targets could also be of potential

AAV: Pathogenesis and Targets for

Treatment interest. Epratuzumab is an anti-CD22 monoclonal antibody. CD22 is expressed on the surface of mature B cells and acts as a negative regulator of $\mathrm{B}$ cell receptor signal transduction. In contrast to $B$ cell depletion by rituximab, it acts as an immunomodulatory agent inducing $B$ cell anergy. Studies in systemic lupus erythematosus have shown potential efficacy and safety $[27,28]$.

Several studies have found elevated levels of B cell-activating factor belonging to the TNF superfamily (BAFF) $[29,30]$. BAFF is a known positive regulator of $B$ cell survival, differentiation, and proliferation. The BAFF receptor is expressed in many stages of the B cell lineage, including plasma cells. In AAV, controversial data exist regarding the correlation between circulating BAFF levels and ANCA titers. Nagai et al. [31] reported increased BAFF levels in active MPA patients which correlated with MPO-ANCA titers. Bader et al. [32] found increased levels in GPA which correlated inversely with ANCA titers. However, we have not found a significant difference in BAFF levels between ANCA-positive and ANCA-negative patients [29]. BAFF might prove to be a potential target for therapy. Belimumab, an anti-BAFF monoclonal antibody, is approved for systemic lupus erythematosus, and is being investigated in a clinical trial as additional relapse prevention therapy for AAV (ClinicalTrials.gov No. NCT01663623). Therefore, a novel therapeutic approach could be maintenance treatment by the anti-BAFF agent belimumab after induction of remission by B celltargeted therapy.

An increasing body of evidence indicates that in autoimmunity the interplay between pathogenic and protective B cell functions is dysregulated. Several studies have found a deficiency in the regulatory B cell compartment. Decreased CD5+ B cells, a B cell population enriched for regulatory cells, were found to be associated with the occurrence of relapses [33]. Additionally, two recent studies found numerical, but not functional, deficiencies in regulatory B cells $[34,35]$. These studies imply a role for the balance between regulatory and effector B cell functions which might have therapeutic implications. Therefore, the future direction for therapy in autoimmunity might not be $\mathrm{B}$ cell depletion, but instead restoring the balance between $\mathrm{B}$ cell regulators and effectors.

\section{T cells}

Several lines of evidence support a role for $\mathrm{T}$ cells in the pathogenesis of AAV [36]. Lymphocyte-depleting therapy, mainly $\mathrm{T}$ cells, with anti-CD52 antibodies 
(alemtuzumab) has been shown to induce remission in AAV patients, suggesting a role of $\mathrm{T}$ cells in disease pathogenesis [37]. We previously demonstrated an imbalance in CD4 $\mathrm{T}$ cell subsets in peripheral blood of patients with AAV [38]. In particular, circulating CD4 $\mathrm{T}$ effector memory $\left(\mathrm{CD} 4+\mathrm{T}_{\mathrm{EM}}\right)$ cells were reduced during active disease, and these cells were detected in the urine of patients and correlated with renal disease activity [39]. Therefore, $\mathrm{CD} 4+\mathrm{T}_{\mathrm{EM}}$ cells are supposed to act as a key trigger of kidney damage and disease expression/relapse in AAV. Importantly, T cell-mediated lesions in AAV patients treated with rituximab (RITUXVAS trial) were shown to be important predictors of renal outcome, whereas the presence of B cells in the renal tissue of those patients did not provide any independent predictor variables related to renal outcome [40]. These results suggest that in addition to anti- $\mathrm{B}$ cell therapy, therapy directed at $\mathrm{T}$ cells, specifically CD4+ $\mathrm{T}_{\mathrm{EM}}$ cells, may improve renal outcomes in AAV.

In this setting, alemtuzumab would not be a suitable therapy since this treatment regimen is associated with severe adverse events in the elderly and those with renal failure [37]. As $\mathrm{CD} 4+\mathrm{T}_{\mathrm{EM}}$ cells are major players in AAV, a promising approach for treating AAV could be to specifically target these effector cells and leave the other T cells untouched. Concerning this issue, Chandy and colleagues [41] have shown that CD4+ $\mathrm{T}_{\mathrm{EM}}$ cells are characterized by high expression of surface Kv1.3 channels (approx. 1,500 channels per cell), whereas naïve and central memory $\mathrm{T}$ cells express lower levels of these channels (approx. 250 channels per cell). Therefore, Kv1.3 channels may serve as an attractive target for specific immunomodulation in $\mathrm{T}_{\mathrm{EM}}$ cell-mediated inflammatory autoimmune diseases. Importantly, selective blockade of Kv1.3 channels ameliorates disease in several animal models without compromising the protective immune responses to acute infection [42, 43]. Gocke et al. [44] found that Kv1.3 is required for expression of proinflammatory cytokines, whereas its absence leads to increased expression of the anti-inflammatory cytokine IL-10. Thus, it is tempting to speculate that pharmacological blockade of Kv1.3 channels contribute to skewing of CD4+ T cell differentiation towards a regulatory phenotype which might be beneficial for autoimmune-mediated vascular diseases. Human phase $1 \mathrm{~A}$ and $1 \mathrm{~B}$ trials of a Kv1.3-blocking agent were recently completed in healthy volunteers, and the efficacy of this agent in patients needs to be assessed.
In AAV patients, persistent $\mathrm{T}$ cell activation has been reported during active disease as well as in remission [38, 45]. Therefore, targeting $\mathrm{T}$ cell activation in AAV by abatacept may represent a potential therapeutic approach. Abatacept is a fully human fusion molecule of cytotoxic T lymphocyte antigen 4 (CTLA4-Ig) and the immunoglobulin Fc region that modulates the CD28-mediated $\mathrm{T}$ cell costimulatory pathway which is required for $\mathrm{T}$ cell activation [46]. It is currently approved for rheumatoid arthritis. An open-label pilot study involving relapsing patients with nonsevere GPA demonstrated sustained disease control with abatacept [47].

Besides targeting $T$ cell activation, one can also consider targeting their effector cytokines, such as IL-17 and IL-21, which are in large part responsible for their pathogenic action. Elevated serum levels of IL-17A and increased autoantigen-specific IL-17-producing cells (Th17) have been demonstrated in AAV patients during disease convalescence compared with healthy controls $[48,49]$. IL-17A cytokines seem operative in lesion development [48]. Therefore, therapeutic approaches targeting IL-17A could be of interest. Several IL-17 A blockers, including the anti-IL-17A monoclonal antibodies secukinumab and ixekizumab and the anti-IL-17 receptor subunit A monoclonal antibody brodalumab have been evaluated in clinical trials $[50,51]$. Secukinumab seems to be the most advanced with respect to clinical evaluation in rheumatoid arthritis [50].

As Th17 cells are pathogenically important in AAV, blocking IL-23, a cytokine essential for the proliferation of Th17 cells, might also have therapeutic potential in AAV. Ustekinumab is an anti-IL-12/23p40 monoclonal antibody, and might be effective in autoimmune disease related to Th17 cells.

Besides IL-17, IL-21-producing cells have also been shown to be increased in AAV patients, which also seems to be an interesting target in the treatment of autoimmune-mediated vascular inflammation [52]. Manipulation of IL-21 may have desirable therapeutic consequences as it must reduce the recruitment of inflammatory Th1 and Th17 cells to inflammatory lesions to prevent tissue damage. Furthermore, it may inhibit expansion of autoreactive B cells. Recently, phase I clinical trials using an IL-21-specific monoclonal antibody (NNC0114-0006) have been completed for rheumatoid arthritis (NCT01208506 and EudraCT-2011-00537642), but were terminated for systemic lupus erythematosus (NCT01689025) [53 ]. Therefore, neutralization of IL-17 or IL-21 could also represent novel therapeutic approaches for patients with AAV. 


\section{Complement}

Recently, several studies have shown the importance of the alternative pathway of complement in the pathogenesis of AAV [54]. Xing et al. [55] detected MAC, C3d, factor $\mathrm{B}$, and factor $\mathrm{P}$ in glomeruli of patients with AAV, indicating involvement of the alternative pathway of complement. Also, elevated levels of plasma and urinary C5a levels were found indicating complement activation in human AAV [56]. Therefore, inhibition of C5a, a cleavage product of complement $\mathrm{C} 5$ with strong chemotactic and anaphylatoxic features, is a potential therapeutic approach. Currently an ongoing phase 2 trial is investigat- ing CCX168, an orally administered small molecule inhibitor of $\mathrm{C} 5 \mathrm{a}$, in patients with AAV (ClinicalTrials.gov No. NCT01363388).

\section{Conclusion}

In AAV, unraveling the pathogenesis has led to various biological targets for therapy. Biological therapies have been successfully introduced or are under evaluation in both clinical and experimental studies. Future clinical studies preferably in international collaboration are warranted to find an optimal place for these new drugs.

\section{References}

$>1$ Jennette JC, Falk RJ, Bacon PA, Basu N, Cid MC, Ferrario F, Flores-Suarez LF, Gross WL, Guillevin L, Hagen EC, Hoffman GS, Jayne DR, Kallenberg CG, Lamprecht P, Langford CA, Luqmani RA, Mahr AD, Matteson EL, Merkel PA, Ozen S, Pusey CD, Rasmussen N, Rees AJ, Scott DG, Specks U, Stone JH, Takahashi K, Watts RA: 2012 revised International Chapel Hill Consensus Conference Nomenclature of Vasculitides. Arthritis Rheum 2013;65:1-11.

$\checkmark 2$ Lyons PA, Rayner TF, Trivedi S, Holle JU, Watts RA, Jayne DR, Baslund B, Brenchley P, Bruchfeld A, Chaudhry AN, Cohen Tervaert JW, Deloukas P, Feighery C, Gross WL, Guillevin L, Gunnarsson I, Harper L, Hruskova Z, Little MA, Martorana D, Neumann T, Ohlsson S, Padmanabhan S, Pusey CD, Salama AD, Sanders JS, Savage CO, Segelmark M, Stegeman CA, Tesar V, Vaglio A, Wieczorek S, Wilde B, Zwerina J, Rees AJ, Clayton DG, Smith KG: Genetically distinct subsets within ANCA-associated vasculitis. N Engl J Med 2012;367:214-223.

>3 Franssen CF, Stegeman CA, Kallenberg CG, Gans RO, De Jong PE, Hoorntje SJ, Tervaert JW: Antiproteinase 3- and antimyeloperoxidase-associated vasculitis. Kidney Int 2000; 57:2195-2206.

-4 Pagnoux C, Hogan SL, Chin H, Jennette JC, Falk RJ, Guillevin L, Nachman PH: Predictors of treatment resistance and relapse in antineutrophil cytoplasmic antibody-associated small-vessel vasculitis: comparison of two independent cohorts. Arthritis Rheum 2008;58: 2908-2918.

5 Stone JH, Merkel PA, Spiera R, Seo P, Langford CA, Hoffman GS, Kallenberg CG, St Clair EW, Turkiewicz A, Tchao NK, Webber L, Ding L, Sejismundo LP, Mieras K, Weitzenkamp D, Ikle D, Seyfert-Margolis V, Mueller M, Brunetta P, Allen NB, Fervenza FC, Geetha D, Keogh KA, Kissin EY, Monach PA, Peikert T, Stegeman C, Ytterberg SR, Specks U;
RAVE-ITN Research Group: Rituximab versus cyclophosphamide for ANCA-associated vasculitis. N Engl J Med 2010;363:221-232.

-6 Specks U, Merkel PA, Seo P, Spiera R, Langford CA, Hoffman GS, Kallenberg CG, St Clair EW, Fessler BJ, Ding L, Viviano L, Tchao NK, Phippard DJ, Asare AL, Lim N, Ikle D, Jepson B, Brunetta P, Allen NB, Fervenza FC, Geetha D, Keogh K, Kissin EY, Monach PA, Peikert T, Stegeman C, Ytterberg SR, Mueller M, Sejismundo LP, Mieras K, Stone JH; RAVE-ITN Research Group: Efficacy of remission-induction regimens for ANCA-associated vasculitis. N Engl J Med 2013;369:417-427.

7 Kallenberg CG, Stegeman CA, Abdulahad WH, Heeringa P: Pathogenesis of ANCA-associated vasculitis: new possibilities for intervention. Am J Kidney Dis 2013;62:11761187.

8 Fauci AS, Haynes BF, Katz P, Wolff SM: Wegener's granulomatosis: prospective clinical and therapeutic experience with 85 patients for 21 years. Ann Intern Med 1983;98:76-85.

-9 Hoffman GS, Kerr GS, Leavitt RY, Hallahan CW, Lebovics RS, Travis WD, Rottem M, Fauci AS: Wegener granulomatosis: an analysis of 158 patients. Ann Intern Med 1992;116: 488-498.

10 Jayne D, Rasmussen N, Andrassy K, Bacon P, Tervaert JW, Dadoniene J, Ekstrand A, Gaskin G, Gregorini G, de Groot K, Gross W, Hagen EC, Mirapeix E, Pettersson E, Siegert C, Sinico A, Tesar V, Westman K, Pusey C; European Vasculitis Study Group: A randomized trial of maintenance therapy for vasculitis associated with antineutrophil cytoplasmic autoantibodies. N Engl J Med 2003;349:3644.

11 Pagnoux C, Mahr A, Hamidou MA, Boffa JJ, Ruivard M, Ducroix JP, Kyndt X, Lifermann F, Papo T, Lambert M, Le Noach J, Khellaf M, Merrien D, Puechal X, Vinzio S, Cohen P, Mouthon L, Cordier JF, Guillevin L; French
Vasculitis Study Group: Azathioprine or methotrexate maintenance for ANCA-associated vasculitis. N Engl J Med 2008;359:27902803.

12 de Joode AA, Sanders JS, Stegeman CA: Renal survival in proteinase 3 and myeloperoxidase ANCA-associated systemic vasculitis. Clin J Am Soc Nephrol 2013;8:1709-1717.

13 Sanders JS, Huitma MG, Kallenberg CG, Stegeman CA: Prediction of relapses in PR3ANCA-associated vasculitis by assessing responses of ANCA titres to treatment. Rheumatology (Oxford) 2006;45:724-729.

14 Boomsma MM, Stegeman CA, van der Leij MJ, Oost W, Hermans J, Kallenberg CG, Limburg PC, Tervaert JW: Prediction of relapses in Wegener's granulomatosis by measurement of antineutrophil cytoplasmic antibody levels: a prospective study. Arthritis Rheum 2000;43:2025-2033.

$\$ 15$ Tomasson G, Grayson PC, Mahr AD, Lavalley M, Merkel PA: Value of ANCA measurements during remission to predict a relapse of ANCA-associated vasculitis - a metaanalysis. Rheumatology (Oxford) 2012;51: 100-109.

16 Bansal PJ, Tobin MC: Neonatal microscopic polyangiitis secondary to transfer of maternal myeloperoxidase-antineutrophil cytoplasmic antibody resulting in neonatal pulmonary hemorrhage and renal involvement. Ann Allergy Asthma Immunol 2004;93:398-401.

17 Xiao H, Heeringa P, Hu P, Liu Z, Zhao M, Aratani Y, Maeda N, Falk RJ, Jennette JC: Antineutrophil cytoplasmic autoantibodies specific for myeloperoxidase cause glomerulonephritis and vasculitis in mice. J Clin Invest 2002;110:955-963.

-18 Little MA, Smyth CL, Yadav R, Ambrose L, Cook HT, Nourshargh S, Pusey CD: Antineutrophil cytoplasm antibodies directed against myeloperoxidase augment leukocyte-microvascular interactions in vivo. Blood 2005;106: 2050-2058 
19 Primo VC, Marusic S, Franklin CC, Goldmann WH, Achaval CG, Smith RN, Arnaout MA, Nikolic B: Anti-PR3 immune responses induce segmental and necrotizing glomerulonephritis. Clin Exp Immunol 2010;159:327337.

-20 Little MA, Al-Ani B, Ren S, Al-Nuaimi H, Leite M Jr, Alpers CE, Savage CO, Duffield JS: Anti-proteinase 3 anti-neutrophil cytoplasm autoantibodies recapitulate systemic vasculitis in mice with a humanized immune system. PLoS One 2012;7:e28626.

21 Silva-Fernandez L, Loza E, Martinez-Taboada VM, Blanco R, Rua-Figueroa I, PegoReigosa JM, Munoz-Fernandez S; Systemic Autoimmune Diseases Study Group of the Spanish Society for Rheumatology (EASSER): Biological therapy for systemic vasculitis: a systematic review. Semin Arthritis Rheum 2014;43:542-557.

-22 Wegener's Granulomatosis Etanercept Trial (WGET) Research Group: Etanercept plus standard therapy for Wegener's granulomatosis. N Engl J Med 2005;352:351-361.

-23 Silva F, Seo P, Schroeder DR, Stone JH, Merkel PA, Hoffman GS, Spiera R, Sebastian JK, Davis JC Jr, St Clair EW, Allen NB, McCune WJ, Ytterberg SR, Specks U; Wegener's Granulomatosis Etanercept Trial Research Group: Solid malignancies among etanercept-treated patients with granulomatosis with polyangiitis (Wegener's): long-term followup of a multicenter longitudinal cohort. Arthritis Rheum 2011;63:2495-2503.

$\checkmark 24$ Jones RB, Tervaert JW, Hauser T, Luqmani R, Morgan MD, Peh CA, Savage CO, Segelmark M, Tesar V, van Paassen P, Walsh D, Walsh M, Westman K, Jayne DR; European Vasculitis Study Group: Rituximab versus cyclophosphamide in ANCA-associated renal vasculitis. N Engl J Med 2010;363:211220.

-25 Voswinkel J, Mueller A, Kraemer JA, Lamprecht P, Herlyn K, Holl-Ulrich K, Feller AC, Pitann S, Gause A, Gross WL: B lymphocyte maturation in Wegener's granulomatosis: a comparative analysis of $\mathrm{VH}$ genes from endonasal lesions. Ann Rheum Dis 2006;65:859864.

26 Cheson BD: Ofatumumab, a novel anti-CD20 monoclonal antibody for the treatment of Bcell malignancies. J Clin Oncol 2010;28:35253530.

27 Wallace DJ, Gordon C, Strand V, Hobbs K, Petri M, Kalunian K, Houssiau F, Tak PP, Isenberg DA, Kelley L, Kilgallen B, Barry AN, Wegener WA, Goldenberg DM: Efficacy and safety of epratuzumab in patients with moderate/severe flaring systemic lupus erythematosus: results from two randomized, doubleblind, placebo-controlled, multicentre studies (ALLEVIATE) and follow-up. Rheumatology (Oxford) 2013;52:1313-1322.

28 Wallace DJ, Kalunian K, Petri MA, Strand V, Houssiau FA, Pike M, Kilgallen B, Bongardt S, Barry A, Kelley L, Gordon C: Efficacy and safety of epratuzumab in patients with mod- erate/severe active systemic lupus erythematosus: results from EMBLEM, a phase IIb, randomised, double-blind, placebo-controlled, multicentre study. Ann Rheum Dis 2014; 73:183-190.

-29 Sanders JS, Huitma MG, Kallenberg CG, Stegeman CA: Plasma levels of soluble interleukin 2 receptor, soluble $\mathrm{CD} 30$, interleukin 10 and $\mathrm{B}$ cell activator of the tumour necrosis factor family during follow-up in vasculitis associated with proteinase 3 -antineutrophil cytoplasmic antibodies: associations with disease activity and relapse. Ann Rheum Dis 2006;65:1484-1489.

30 Schneeweis C, Rafalowicz M, Feist E, Buttgereit F, Rudolph PE, Burmester GR, Egerer $\mathrm{K}$ : Increased levels of BLyS and sVCAM-1 in anti-neutrophil cytoplasmatic antibody (ANCA)-associated vasculitides (AAV). Clin Exp Rheumatol 2010;28:62-66.

31 Nagai M, Hirayama K, Ebihara I, Shimohata H, Kobayashi M, Koyama A: Serum levels of BAFF and APRIL in myeloperoxidase antineutrophil cytoplasmic autoantibody-associated renal vasculitis: association with disease activity. Nephron Clin Pract 2011;118:c339c345.

32 Bader L, Koldingsnes W, Nossent J: B-lymphocyte activating factor levels are increased in patients with Wegener's granulomatosis and inversely correlated with ANCA titer. Clin Rheumatol 2010;29:1031-1035.

33 Bunch DO, McGregor JG, Khandoobhai NB, Aybar LT, Burkart ME, Hu Y, Hogan SL, Poulton CJ, Berg EA, Falk RJ, Nachman PH: Decreased CD5(+) B cells in active ANCA vasculitis and relapse after rituximab. Clin J Am Soc Nephrol 2013;8:382-391.

34 Lepse N, Abdulahad WH, Rutgers A, Kallenberg CG, Stegeman CA, Heeringa P: Altered $B$ cell balance, but unaffected B cell capacity to limit monocyte activation in anti-neutrophil cytoplasmic antibody-associated vasculitis in remission. Rheumatology (Oxford) 2014;53:1683-1692.

35 Todd SK, Pepper RJ, Draibe J, Tanna A, Pusey CD, Mauri C, Salama AD: Regulatory B cells are numerically but not functionally deficient in anti-neutrophil cytoplasm antibody-associated vasculitis. Rheumatology (Oxford) 2014;53:1693-1703.

- 36 Abdulahad WH, Lamprecht P, Kallenberg CG: T-helper cells as new players in ANCAassociated vasculitides. Arthritis Res Ther 2011;13:236

37 Walsh M, Chaudhry A, Jayne D: Long-term follow-up of relapsing/refractory anti-neutrophil cytoplasm antibody associated vasculitis treated with the lymphocyte depleting antibody alemtuzumab (CAMPATH-1H). Ann Rheum Dis 2008;67:1322-1327.

- 38 Abdulahad WH, van der Geld YM, Stegeman CA, Kallenberg CG: Persistent expansion of CD4+ effector memory T cells in Wegener's granulomatosis. Kidney Int 2006;70:938-947.

- 39 Abdulahad WH, Kallenberg CG, Limburg PC, Stegeman CA: Urinary CD4+ effector memory T cells reflect renal disease activity in antineutrophil cytoplasmic antibody-associated vasculitis. Arthritis Rheum 2009;60: 2830-2838.

-40 Berden AE, Jones RB, Erasmus DD, Walsh M, Noel LH, Ferrario F, Waldherr R, Bruijn JA, Jayne DR, Bajema IM; European Vasculitis Society: Tubular lesions predict renal outcome in antineutrophil cytoplasmic antibody-associated glomerulonephritis after rituximab therapy. J Am Soc Nephrol 2012; 23:313-321.

41 Wulff H, Calabresi PA, Allie R, Yun S, Pennington $\mathrm{M}$, Beeton $\mathrm{C}$, Chandy KG: The voltage-gated $\mathrm{Kv1.3} \mathrm{K}(+)$ channel in effector memory T cells as new target for MS. J Clin Invest 2003;111:1703-1713

$\checkmark 42$ Beeton C, Wulff H, Standifer NE, Azam P, Mullen KM, Pennington MW, Kolski-Andreaco A, Wei E, Grino A, Counts DR, Wang PH, LeeHealey CJ, S Andrews B, Sankaranarayanan A, Homerick D, Roeck WW, Tehranzadeh J, Stanhope KL, Zimin P, Havel PJ, Griffey S, Knaus HG, Nepom GT, Gutman GA, Calabresi PA, Chandy KG: Kv1.3 channels are a therapeutic target for T cell-mediated autoimmune diseases. Proc Natl Acad Sci U S A 2006;103:17414-17419.

43 Tarcha EJ, Chi V, Munoz-Elias EJ, Bailey D, Londono LM, Upadhyay SK, Norton K, Banks A, Tjong I, Nguyen H, Hu X, Ruppert GW, Boley SE, Slauter R, Sams J, Knapp B, Kentala D, Hansen Z, Pennington MW, Beeton $\mathrm{C}$, Chandy KG, Iadonato SP: Durable pharmacological responses from the peptide ShK-186, a specific Kv1.3 channel inhibitor that suppresses $\mathrm{T}$ cell mediators of autoimmune disease. J Pharmacol Exp Ther 2012; 342:642-653

44 Gocke AR, Lebson LA, Grishkan IV, Hu L, Nguyen HM, Whartenby KA, Chandy KG, Calabresi PA: Kv1.3 deletion biases T cells toward an immunoregulatory phenotype and renders mice resistant to autoimmune encephalomyelitis. J Immunol 2012;188:58775886.

45 Popa ER, Stegeman CA, Bos NA, Kallenberg CG, Tervaert JW: Differential B- and T-cell activation in Wegener's granulomatosis. J Allergy Clin Immunol 1999;103:885-894.

46 Reiser H, Stadecker MJ: Costimulatory B7 molecules in the pathogenesis of infectious and autoimmune diseases. N Engl J Med 1996;335:1369-1377.

47 Langford CA, Monach PA, Specks U, Seo P, Cuthbertson D, McAlear CA, Ytterberg SR, Hoffman GS, Krischer JP, Merkel PA; Vasculitis Clinical Research Consortium: An openlabel trial of abatacept (CTLA4-IG) in nonsevere relapsing granulomatosis with polyangiitis (Wegener's). Ann Rheum Dis 2014;73: 1376-1379.

48 Abdulahad WH, Stegeman CA, Limburg PC, Kallenberg CG: Skewed distribution of Th17 lymphocytes in patients with Wegener's granulomatosis in remission. Arthritis Rheum 2008;58:2196-2205. 
49 Nogueira E, Hamour S, Sawant D, Henderson S, Mansfield N, Chavele KM, Pusey CD, Salama AD: Serum IL-17 and IL-23 levels and autoantigen-specific Th17 cells are elevated in patients with ANCA-associated vasculitis. Nephrol Dial Transplant 2010;25:2209-2217.

50 Kellner H: Targeting interleukin-17 in patients with active rheumatoid arthritis: rationale and clinical potential. Ther Adv Musculoskelet Dis 2013;5:141-152.

- 51 Brown G, Malakouti M, Wang E, Koo JY, Levin E: Anti-IL-17 phase II data for psoriasis: a review. J Dermatolog Treat 2014, Epub ahead of print.
52 Abdulahad WH, Lepse N, Stegeman CA, Huitema MG, Doornbos-van der Meer B, Tadema H, Rutgers A, Limburg PC, Kallenberg CG, Heeringa P: Increased frequency of circulating IL-21 producing Th-cells in patients with granulomatosis with polyangiitis (GPA). Arthritis Res Ther 2013;15:R70.

53 Spolski R, Leonard WJ: Interleukin-21: a double-edged sword with therapeutic potential. Nat Rev Drug Discov 2014;13:379-395.

54 Yuan J, Chen M, Zhao MH: Complement in antineutrophil cytoplasmic antibody-associated vasculitis. Clin Exp Nephrol 2013;17: 642-645.
5 Xing GQ, Chen M, Liu G, Heeringa P, Zhang JJ, Zheng X, E J, Kallenberg CG, Zhao MH: Complement activation is involved in renal damage in human antineutrophil cytoplasmic autoantibody associated pauci-immune vasculitis. J Clin Immunol 2009;29:282-291.

56 Yuan J, Gou SJ, Huang J, Hao J, Chen M, Zhao $\mathrm{MH}$ : $\mathrm{C} 5 \mathrm{a}$ and its receptors in human antineutrophil cytoplasmic antibody (ANCA)associated vasculitis. Arthritis Res Ther 2012. 14:R140.

57 Lepse N, Abdulahad WH, Kallenberg CG, Heeringa P: Immune regulatory mechanisms in ANCA-associated vasculitides. Autoimmun Rev 2011;11:77-83. 